\title{
Continu verbeteren in een Vlaams woonzorgcentrum: ook beter voor zorgverleners?*
}

\author{
Michiel Bal, Jos Benders \& Lander Vermeerbergen**
}

Continu verbeteren (CVB) van werkprocessen maakt vanaf het begin van de $21^{e}$ eeuw opmars in de zorg. Tot hiertoe bleef onduidelijk welke gevolgen dit heeft voor de kwaliteit van de arbeid bij zorgverleners. In dit artikel wordt de kwaliteit van de arbeid onderzocht in De Vierde Wand, een Vlaams woonzorgcentrum waar men CVB sinds begin 2015 toepast. Een kwantitatieve vergelijking met 'conventionele' woonzorgcentra toont dat de zorgverleners in De Vierde Wand lagere werkeisen, meer regelmogelijkheden en een verhoogde bevlogenheid rapporteren. Aan de hand van kwalitatieve data schrijven we dit verschil in belangrijke mate toe aan CVB. Hoewel continu verbeteren in dit woonzorgcentrum positief uitpakt voor de kwaliteit van de arbeid, komen in dit artikel ook enkele concrete verbeterpunten voor het toepassen van CVB in dit woonzorgcentrum naar voren.

\section{Inleiding}

In Vlaanderen rapporteren zorgmedewerkers in woonzorgcentra meer knelpunten in de kwaliteit van de arbeid dan werknemers elders in de zorg en in andere sectoren (Bourdeaud'hui, Janssens, \& Vanderhaeghe, 2017; Tummers, Groeneveld, \& Lankhaar, 2013). Bovendien lijkt de kwaliteit van de arbeid in woonzorgcentra achteruit te gaan door een verhoging van de werkdruk. Van het huidige aantal zorgverleners verwacht men immers dat ze met de aanhoudende vergrijzing een groter aantal zorgbehoeftigen zullen opvangen (Goetghebeur \& Sevenants, 2017). Zeker nu de vraag naar zorgverleners toeneemt, is de aantrekkingskracht van zorgjobs van cruciaal belang.

Om de arbeidskrapte in de woonzorgsector het hoofd te bieden worden dan ook de nodige organisatorische en technologische veranderingen doorgevoerd. Eén daarvan is continu verbeteren (CVB; Rouppe van der Voort \& Benders, 2012). Hiermee beoogt men doorlopend werkprocessen te verbeteren om een betere kwaliteit te kunnen leveren, efficiënter te werken en/of het werk aangenamer in te richten. Toegepast op de zorgsector zou continu verbeteren moeten resulteren in (1) een betere kwaliteit van de zorg, (2) efficiëntere zorgverlening, en (3) een aangenamere werkplek (Rouppe van der Voort \& Benders, 2012). Of deze eerste

* We bedanken de medewerkers en de directeur-eigenaren van De Vierde Wand voor hun intensieve medewerking, en de redactie en reviewers van TvA voor hun commentaren op een eerdere versie van dit artikel.

** Michiel Bal, Jos Benders en Lander Vermeerbergen zijn verbonden aan de Katholieke Universiteit Leuven, Centrum voor Sociologisch Onderzoek. Jos Benders is tevens verbonden aan de NTNU, Departement voor Industriële Economie en Technologie Management (Trondheim). E-mail: michiel.bal@kuleuven.be. 
twee doelstellingen behaald worden, hangt in belangrijke mate samen met de derde, met name de attitude van zorgverleners ten opzichte van CVB. Daarom is het dus van belang om zicht te krijgen op de invloed van CVB op de kwaliteit van de arbeid in woonzorgcentra.

De huidige aandacht voor CVB komt voort uit het bredere begrip lean. Dit organisatieconcept komt voort uit onderzoek uit de jaren 1980 naar de prestaties van autofabrieken. Daarin werd gesteld dat de door Toyota geïnitieerde manier van produceren superieur was. Vanaf ongeveer het jaar 2000 vormt lean ook in de zorg een inspiratiebron voor allerlei organisatieveranderingen. In de Nederlandse zorg is het belang van CVB, een cruciaal onderdeel van lean, benadrukt als manier om zorgprocessen te verbeteren (Benders, Van Grinsven, \& Ingvaldsen, 2019; Rouppe van der Voort \& Benders, 2012).

Tot hiertoe is de enige consistentie in onderzoek naar de invloed van lean op de kwaliteit van de arbeid echter dat de resultaten inconsistent zijn (Benders, 2017; d'Andreamatteo, Ianni, Lega, \& Sargiacomo, 2015; Neirotti, 2019). Een eerste reden hiervoor is dat lean om uiteenlopende redenen ingevoerd kan zijn. Men kan met de invoering verschillende doelen voor ogen hebben, maar waar focust men op? Voornamelijk op een betere kwaliteit van de zorg, op meer efficiëntie in de zorgverlening, of eerder op een verbeterde kwaliteit van de arbeid (Hasle, 2014; Håkansson, Holden, Eriksson, \& Dellve, 2017)? Ten tweede zijn de resultaten uiteenlopend omdat het concept lean op verschillende manieren wordt geïnterpreteerd, ingevoerd en toegepast. Dit zorgt ervoor dat een erg brede empirische realiteit de algemene lean-stempel draagt (Benders, 2017; Ortmann, 1995). Ten derde speelt de lokale context van organisaties een belangrijke rol. Ook dit ligt aan de basis van inconsistente resultaten. In algemene zin stelt Walshe (2007) dat variatie in resultaten niet alleen te wijten is aan de bestudeerde organisatieverandering zelf, maar ook aan de context waarin de interventie tot stand gekomen is. Dynamiek en bereidheid tot veranderen zijn bijvoorbeeld enkele factoren die mede bepalend zijn voor een succesvolle implementatie (Andersen, Røvik, \& Ingebrigtsen, 2014; Von Thiele-Schwarz, Nielsen, Stenfors-Hayes, \& Hasson, 2017).

In dit artikel willen we in kaart brengen wat de invloed van CVB is op de kwaliteit van de arbeid voor zorgjobs in een Vlaams woonzorgcentrum. Daarmee perken we het bredere begrip lean dus in tot CVB. In wat volgt gaan we daarom eerst in op CVB en hoe dit concept vorm krijgt in de zorgsector. Vervolgens gaan we aan de hand van surveydata na of de kwaliteit van de arbeid in De Vierde Wand te Winterslag, regio Genk, verschilt van die in negen vergelijkbare 'conventionele' woonzorgcentra zonder CVB. De cijfergegevens worden nadien ingekleurd met interviewdata. Op deze manier (1) verklaren we de kwantitatieve resultaten en (2) staan we stil bij wat we nu precies kunnen toekennen aan continu verbeteren. Ten slotte vatten we de belangrijkste bevindingen samen in de conclusie.

\section{Continu verbeteren}

Continu verbeteren (CVB) wordt in het Japans ook wel kaizen genoemd. Dit woord bestaat uit het samenvoegen van kai (verandering) en zen (goed). Bij CVB ligt 
de focus op het systematisch streven naar betere werkmethoden. Deze werkmethoden worden na overleg vastgelegd als standaardprocedures. Het is van belang dat dergelijke procedures opgesteld worden door degenen die ermee zullen werken, of op zijn minst met hun inbreng. Iedereen kan immers gezien worden als deskundige voor zijn of haar eigen werkzaamheden. Bijgevolg is iedere medewerker binnen zijn of haar werkgebied het meest geschikt om (1) te beoordelen of een bepaalde procedure in de praktijk wel werkt, (2) te signaleren waar verbetering mogelijk is, en (3) nieuwe werkprocedures voor te stellen. Dat zijn meteen ook de redenen waarom de zorgverleners in De Vierde Wand op regelmatige basis samenkomen om de standaardprocedures collectief te evalueren.

Tijdens deze evaluatiemomenten bekrachtigen ze de succesvolle standaardprocedures en bespreken ze eventuele problemen en frustraties waarop ze stuiten. Voor wat moeizaam werken lijkt, wordt als groep vervolgens een andere aanpak bedacht (Drotz \& Poksinska, 2014). Pas wanneer deze aanpak door de aanwezige zorgverleners erkend wordt, zetten ze deze voor een overeengekomen deadline om in realiteit. Het mag duidelijk zijn dat gedisciplineerde, toegewijde zorgverleners essentieel zijn voor het slagen van CVB. Het engagement dat zorgverleners erop nahouden, hangt ook samen met de context van de zorginstelling (Huo \& Boxall, 2018; Walshe, 2007). Zo moet het management bereid zijn de ruimte te creëren, en het personeel te motiveren voor regelmatig collectief overleg in het kader van CVB (Andersen et al., 2014; Von Thiele Schwarz et al., 2017).

\section{De kwaliteit van de arbeid in woonzorgcentra: conventioneel versus continu verbeteren}

Om de invloed van continu verbeteren (CVB) op de kwaliteit van de arbeid bij zorgverleners te meten wordt beroep gedaan op het 'job demands-control'-model (Karasek, 1979). Dit model stelt twee aspecten van een job centraal, met name werkeisen en regelmogelijkheden. Werkeisen zijn aspecten van de job die voortdurend fysieke of psychische inspanning vergen van werknemers. Dit zijn werkdruk, tijdsdruk, taakvariatie, voorspelbaarheid, volledigheid, kortcyclisch werk en emotionele belasting. Autonomie en informatiebeschikbaarheid behoren vervolgens tot de regelmogelijkheden. Regelmogelijkheden hebben betrekking op de ruimte die een werknemer heeft om het eigen werk te organiseren en op de ondersteunende feedback die men kan geven en/of krijgen (Karasek \& Theorell, 1990; Vermeerbergen, 2018). Het is van belang om te ijveren voor jobs met een balans tussen deze twee aspecten: werknemers moeten immers over de regelmogelijkheden beschikken die nodig zijn om aan de werkeisen te kunnen voldoen (Karasek, 1979; Van Hootegem, Huys, Dhondt, \& Kraan, 2014).

Uit empirisch onderzoek blijkt dat jobs in Vlaamse woonzorgcentra vergeleken met die in andere sectoren over het algemeen worden gekenmerkt door hogere werkeisen en lagere regelmogelijkheden (Bourdeaud'hui et al., 2017). Dit resulteert in een lagere kwaliteit van de arbeid voor de zorgsector met een verhoogd risico op burn-out, meer verzuim, een hoger verloop, een lagere bevlogenheid, fysieke uitputting en een hogere herstelbehoefte als mogelijke gevolgen (Demerouti, Bakker, Nachreiner, \& Schaufeli, 2000; Proost, De Witte, De Witte, \& Evers, 
2004). Op basis van deze literatuur en de theoretische bijdrage omtrent CVB werden hypothesen opgesteld in Tabel 1.

Tabel 1 Hypothesen over de verschillende werkeisen, regelmogelijkheden en zorgverlenersuitkomsten voor woonzorgcentra die CVB toepassen en conventionele woonzorgcentra (CWZC)

$\begin{array}{llc} & & \text { Ten opzichte van CWZC } \\ \text { Werkeisen } & \text { Kortcyclisch werk } & > \\ \text { Voorspelbaarheid } & > \\ \text { Taakvariatie } & > \\ \text { Volledigheid } & > \\ \text { Tijdsdruk } & < \\ \text { Werkdruk } & > \\ \text { Regelmogelijkheden } & \text { Emotionele belasting } & > \\ & \text { Autonomie } & > \\ \text { Informatievoorziening } & > \\ \text { Uitkomsten zorgverleners } & \text { Contactmogelijkheden } & > \\ & \text { Organiserende taken } & < \\ & \text { Berstelbehoefte } & >\end{array}$

Noot. Op basis van het onderstaande literatuuronderzoek toont Tabel I de hypothesen over verschillende werkeisen en regelmogelijkheden. De symbolen '<' en '>' staan voor de verwachting dat de score op de betreffende werkeis bij het woonzorgcentrum dat CVB toepast lager ('<') respectievelijk hoger ('>') zal liggen dan in de conventionele woonzorgcentra.

Hieronder volgt een overzicht van de literatuur over werkeisen en regelmogelijkheden van zorgjobs in conventionele woonzorgcentra. Deze wordt naast de literatuur over CVB en kwaliteit van de arbeid gelegd om de hypothesen te verantwoorden. Er wordt achtereenvolgens stilgestaan bij werkeisen en regelmogelijkheden. Ook de uitkomsten voor zorgverleners uit Tabel 1 komen in wat volgt naar voren.

In conventionele woonzorgcentra wekken en wassen zorgverleners bewoner na bewoner, kamer in, kamer uit tijdens de ochtendshifts. Ondanks de persoonsspecifieke noden van de bewoners, geeft dit een indruk van het sterk kortcyclische en voorspelbare karakter van de ochtendtaken in conventionele woonzorgcentra weer (De Rooij et al., 2012). Wat dat betreft trekt CVB het keurslijf van de taken nog wat strakker. Hierdoor komt tijd vrij die naar meer bewonersgerichte zorg zou kunnen gaan.

Benders, Bleijerveld en Schouteten (2017) concluderen dat door CVB toe te passen in een context met weinig taakvariatie de nadruk op strakke repetitie leidt tot het nog monotoner maken van al sterk gestandaardiseerde banen. Door te focussen op afgelijnde taken verliezen zorgverleners bovendien zicht op het volledige zorgproces (De Treville \& Antonakis, 2006). In een context met hoge taakvariatie en weinig repetitie leidt CVB daarentegen tot het scheppen van orde in de chaos en bijgevolg tot een soepeler verloop van de werkprocessen (Benders et al., 2017). Het ziet er dus naar uit dat de invloed van CVB op de kwaliteit 
van de arbeid afhankelijk is van het niveau van taakvariatie (Benders et al., 2017; Conti, Angelis, Cooper, Faragher, \& Gill, 2006; Drotz \& Poksinska, 2014). In beide gevallen is er dus sprake van een hogere mate van structurering van de werkzaamheden, maar afhankelijk van de uitgangssituatie zal die negatief dan wel positief worden gewaardeerd. In lijn met de structurering van de werkzaamheden verwachten we dat zorgverleners de samenhang tussen voorbereidende, uitvoerende en ondersteunende taken sterker zullen zien dankzij CVB. Ook werkdruk en emotionele belasting zijn van belang voor de kwaliteit van de arbeid in woonzorgcentra (Bourdeaud'hui \& et al., 2017; Karimi, Leggat, Donohue, Farrell, \& Couper, 2014; Vermeerbergen, Van Hootegem, \& Benders, 2016). Werkdruk wordt ervaren wanneer men het gevoel heeft het werk niet gedaan te krijgen. Door het elimineren van taken die bij nadere bestudering overbodig blijken te zijn en het efficiënter inrichten van processen, neemt de hoeveelheid werk en dus de werkdruk af. In lijn hiermee wordt verwacht dat tijdsdruk lager zal liggen in woonzorgcentra met een CVB-toepassing.

Vervolgens is ook emotionele belasting een pijnpunt voor zorgverleners in woonzorgcentra (Karimi et al., 2014; Vermeerbergen et al., 2016): deze wordt hoger naarmate de binding met zorgbehoeftige residenten toeneemt (Vermeerbergen et al., 2016). Als CVB ook inzet op bewonersgerichte zorg is het dus waarschijnlijk dat het zorgpersoneel door CVB te kampen krijgt met een verhoogde emotionele belasting (Conti et al., 2006). Over het algemeen lijken de werkeisen in woonzorgcentra die CVB toepassen lager dan in woonzorgcentra die CVB niet toepassen.

Wat betreft de regelmogelijkheden, verschilt de intensiteit van sociale ondersteuning en mogelijkheden tot contact van woonzorgcentrum tot woonzorgcentrum. Het is wel zo dat feedback geven in conventionele woonzorgcentra vaak wordt ingeperkt tot een maandelijkse bijeenkomst (De Rooij et al., 2012). Dit is allerminst te vergelijken met de dagelijkse bijeenkomsten in woonzorgcentra die continu verbeteren toepassen. Op regelmatige basis bijeenkomen draagt niet alleen bij tot verbeterde communicatie tussen medewerkers onderling, maar helpt ook het bottom-up doorspelen van de informatie. Het draagt dus bij tot een intensivering van de contactmogelijkheden (De Treville \& Antonakis, 2006; Drotz \& Poksinska, 2014; Ulhassan, Von Thiele Schwarz, Westerlund, Sandahl, \& Thor, 2015). In woonzorgcentra die CVB toepassen is er zoals vermeld steeds de mogelijkheid om werkmethoden te organiseren, aan te passen en te coördineren. Concreet stelt het management het zorgpersoneel dus in staat om de grenzen van afgelijnde standaardprocedures in vraag te stellen en deze zelf in te vullen (De Treville \& Antonakis, 2006; Liker, 2004; Ulhassan et al., 2015). Dankzij toegenomen decentrale beslissingsbevoegdheden beschikken zorgverleners over hogere autonomie in vergelijking met hun collega's uit conventionele woonzorgcentra (Ballé \& Régnier, 2007; Benders \& Missiaen, 2013). Een opmerking hierbij is dat een toename van decentrale beslissingsmogelijkheden autonomie ook kan beknotten. Zorgverleners hebben immers minder manoeuvreerruimte binnen de taken die ze zelf aflijnen (Benders \& Missiaen, 2013; De Treville \& Antonakis, 2006). De Treville en Antonakis (2006) geven aan dat dit niet opweegt tegen voordelen van decentraal regelen.

Op basis van voorgaand literatuuronderzoek lijkt CVB te leiden tot lagere werkeisen en hogere regelmogelijkheden. Bijgevolg wordt verwacht dat CVB 
positieve invloed heeft op de kwaliteit van de arbeid in de ouderenzorg. Specifiek leiden de lagere werkeisen tot een daling in de behoefte tot herstel aan het eind van de werkdag (Karasek, 1979). Daarnaast zorgen hogere regelmogelijkheden ten gevolge van CVB voor een toegenomen bevlogenheid en meer innovatief werkgedrag (Benders et al., 2017; Huo \& Boxall, 2018).

\section{Methodologie}

Om zicht te krijgen op de kwaliteit van de arbeid voor woonzorgcentra die continu verbeteren (CVB) toepassen worden zowel kwantitatieve als kwalitatieve data gebruikt. De surveydata maken mogelijk kwantitatief te vergelijken tussen het woonzorgcentrum dat continu verbeteren toepast en negen conventionele woonzorgcentra (Baxter \& Jack, 2008). Nadien volgt een kwalitatieve sectie op basis van interviewdata. In deze sectie komen de verklaringen voor de gevonden verschillen naar voren: hierbij wordt een onderscheid gemaakt tussen (1) de effecten van CVB in het woonzorgcentrum, en (2) de invloed van de specifieke organisatiecontext op de kwaliteit van de arbeid (Walshe, 2007). Door op deze manier gebruik te maken van verschillende data kunnen genuanceerde uitspraken gedaan worden over de invloed van CVB op de kwaliteit van arbeid in woonzorgcentra.

\section{Surveys}

Voor het kwantitatieve luik werden 553 vragenlijsten ingevuld tussen juni 2016 en juni 2017. In de negen conventionele woonzorgcentra werden 512 van de 891 verzonden vragenlijsten ingevuld (responsgraad: 58\%). Van de 58 uitgedeelde vragenlijsten in het woonzorgcentrum dat CVB toepast werden er 41 ingevuld (responsgraad: 71\%). Een non-responsanalyse toonde aan dat er geen significante verschillen waren tussen de respondenten en de non-respondenten betreffende geslacht, leeftijd, opleidingsniveau, zorgfunctie en contractuele tewerkstelling (voltijds versus deeltijds).

Bij het opstellen van de vragenlijst werd de NOVA-WEBA-FLA-SY gebruikt (Van Hootegem et al., 2014). Volgende indicatoren werden opgenomen: kortcyclisch werk (twee items, $\alpha=0,61$ ), voorspelbaarheid (vijf items, $\alpha=0,62$ ), taakvariatie (vijf items, $\alpha=0,62$ ), volledigheid (vijf items, $\alpha=0,68$ ), tijdsdruk (vier items, $\alpha=0,70$ ), emotionele belasting (drie items, $\alpha=0,63$ ), autonomie (negen items, $\alpha=0,82$ ), informatievoorziening (vier items, $\alpha=0,85$ ) en contactmogelijkheden (elf items, $\alpha=0,70$ ). Naar aanleiding van het Belgische Koninklijk Besluit betreffende de preventie van psychosociale risico's op het werk, werd het construct werkdruk hieraan toegevoegd (B.S. 28.04.14). Daarnaast werden herstelbehoefte (vier items, $\alpha=0,83$ ), bevlogenheid (zeven items, $\alpha=0,92$ ) en innovatief werkgedrag (vier items, $\alpha=0,77$ ) meegenomen als uitkomsten voor een kwaliteitsvolle of minder kwaliteitsvolle job. De gebruikte Likertschalen voor deze indicatoren lopen van 1 tot 5 (van 'helemaal mee oneens' tot en met 'helemaal mee eens') met uitzondering van 'bevlogenheid'. Deze loopt namelijk van 1 tot 7 ('nooit' tot en met 'altijd') en is gebaseerd op zeven items uit de UBES (Schaufeli \& Bakker, 2004).

De absolute scores op de dimensies van de kwaliteit van de arbeid zijn bij gebrek aan normen niet eenduidig te interpreteren. Daarom wordt voornamelijk gekeken 
naar het relatieve verschil tussen het woonzorgcentrum dat CVB toepast en het referentiekader van negen conventionele woonzorgcentra. Omdat de opgestelde hypothesen (zie Tabel 1) de richting van de verwachte effecten duidelijk weergeven, werden de data geanalyseerd met eenzijdige t-tests. P-waarden onder 0,05 werden significant beschouwd. Deze kwantitatieve methode geeft een indicatie voor de situering van De Vierde Wand ten opzichte van de conventionele woonzorgcentra.

\section{Interviews}

Met kwalitatieve data wordt de kwantitatieve situering van woonzorgcentra die continu verbeteren toepassen ten opzichte van conventionele woonzorgcentra verklaard. Hiervoor wordt gebruikgemaakt van dertien semigestructureerde interviews en bekeken in hoeverre de verschillen in de scores tussen conventionele en 'continu verbeter'-woonzorgcentra effectief te wijten zijn aan CVB (Yin, 2015). Dit impliceert dat er in het kwalitatieve luik tevens oog is voor contexteffecten: de effecten die niet zozeer te maken hebben met CVB, maar meer te wijten zijn aan de organisatiecontext van de case (Walshe, 2007).

Medio 2017 namen zes zorgkundigen, drie verpleegkundigen en vier andere medewerkers op vrijwillige basis deel aan de interviews. De gemiddelde geïnterviewde gebruikte 45 minuten om zijn of haar ervaringen te delen. Tijdens de interviews werd als eerste een open vraag gesteld over CVB. Zo werd meteen duidelijk welke aspecten de medewerkers sterk relateerden aan CVB. De focus doorheen de interviews lag op zowel retrospectieve als actuele ervaringen met betrekking tot de zorgverlening. De transcripten van de interviews werden geanalyseerd en gecodeerd (Corley \& Gioia, 2011). Op 25 oktober 2017 zijn de resultaten voorgesteld gedurende een openbare bijeenkomst in De Vierde Wand in aanwezigheid van de geïnterviewde medewerkers, niet-geïnterviewde medewerkers en de directie. De organisatie kon zich vinden in deze resultaten. Hierdoor heeft de presentatie niet geleid tot aanpassingen van de initiële bevindingen.

\section{Empirische context}

De Vierde Wand, tot op heden het enige woonzorgcentrum in Vlaanderen dat continu verbeteren (CVB) toepast, is een commercieel woonzorgcentrum met 84 bedden. Het woonzorgcentrum werd in Genk-Winterslag door de huidige directeur-eigenaren (een echtpaar) opgericht en opende eind 2012 zijn deuren. De directeur-eigenaren zijn sindsdien erg betrokken bij de werking om hun opvattingen over goede zorg in het woonzorgcentrum waar te maken. In 2015 werd continu verbeteren in De Vierde Wand geïntroduceerd. Van meet af aan ijverden de directeur-eigenaren voor een intensieve toepassing van deze methode. Het is van belang te vermelden dat beide eigenaren het CVB sterk volgens het boekje toepassen. Dagelijks worden de medewerkers gestimuleerd om in het kader van CVB tien à vijftien minuten bijeen te komen aan een zogenoemd 'verbeterbord'. Tijdens deze bijeenkomsten wordt besproken hoe ze de opgemerkte problemen uit de werking kunnen weren. Zodra een verbetervoorstel draagvlak vindt bij de zorgverleners wordt dit voorstel (na testfase) de nieuwe standaardprocedure. Vanaf dat moment worden alle zorgverleners geacht zich aan deze nieuwe procedure te houden, tenzij alsnog blijkt dat deze in de praktijk niet goed functioneert. In dat geval belandt deze standaardprocedure opnieuw aan 
het verbeterbord. Op deze verbeterborden worden de actuele problemen volgens de gekende structuur genoteerd. In een eerste kolom worden de vastgestelde problemen beknopt omschreven. In de volgende kolommen zijn onder meer verbetervoorstellen, verantwoordelijken voor de opvolging en deadlines voor het implementeren van de nieuwe standaardprocedures terug te vinden. Bijeenkomsten aan deze verbeterborden doelen in De Vierde Wand op een collectieve en reflexieve aanpak van de actuele problemen.

Tijdens het onderzoek bestond het personeelsbestand in deze zorginstelling uit 38 zorgmedewerkers, 5 verpleegkundigen en 16 ondersteunende personeelsleden. Het genormeerde aantal voltijdse equivalenten (VTE) werd vanaf de oprichting van De Vierde Wand overschreden met 10 VTE (Agentschap Zorg en Gezondheid, 2017). Naast een hoge bezettingsgraad zijn ook de nieuwbouw en de moderne infrastructuur typerend voor dit woonzorgcentrum.

Ook voor de referentiegroep van de conventionele woonzorgcentra werd het bewoners- en het zorgverlenersaantal geaggregeerd, in Tabel 2. De negen 'conventionele' woonzorgcentra uit de referentiegroep zijn woonzorgcentra die actief op zoek zijn om via veranderingen in hun arbeidsorganisatie te ijveren voor een betere kwaliteit van de arbeid. Hiervoor namen deze negen woonzorgcentra deel aan een programma dat werd opgericht door Flanders Synergy (Workitects). De gebruikte data van deze negen woonzorgcentra komt voort uit nulmetingen die aan de interventies voorafgingen. Dit is de reden waarom ze beschouwd worden als gepast referentiekader, al beschikken we niet over gegevens over de bedrijfsvoering in deze negen woonzorgcentra.

Tabel 2 geeft specifiek de gemiddelde bewoners- en zorgverlenersaantallen voor de referentiegroep van negen conventionele woonzorgcentra en de aantallen uit De Vierde Wand. Twee zaken zijn opvallend: (1) de absolute aantallen liggen steeds hoger in de conventionele woonzorgcentra en (2) het aantal bewoners per zorgverlener ligt net hoger bij conventionele woonzorgcentra.

Tabel 2 Bewoners- en zorgverlenersaantallen in conventionele woonzorgcentra $(C W Z C)$ en in De Vierde Wand (DVW).

\begin{tabular}{lcc}
\hline & CWZC & DVW \\
\hline Bewonersaantal & 142 & 84 \\
Zorgverlenersaantal & 92 & 58 \\
Ratio (bewonersaantal/zorgverlenersaantal) & 1,54 & 1,45 \\
\hline
\end{tabular}

Bron: Personeelsbestand DVW, 2018; Personeelsbestand Referentiekader, 2017

Tabel 3 vergelijkt de achtergrondkenmerken van de respondenten in De Vierde Wand met deze in de referentiegroep. Voor geslacht, functietype, opleidingsniveau en contractuele tewerkstelling zijn geen significante verschillen gevonden. Vooral de gemiddelde anciënniteit bij de werkgever (12 versus 4 jaar) maar ook de gemiddelde leeftijd (40 versus 36 jaar) liggen wel significant lager in De Vierde Wand, aangezien dit woonzorgcentrum pas in 2012 opende. We zien geen aanleiding te veronderstellen dat deze twee kenmerken van invloed zijn op de scores voor werkeisen en regelmogelijkheden. 
Tabel 3 Algemene kenmerken van de werknemers in de conventionele woonzorgcentra $(C W Z C)$ in vergelijking met De Vierde Wand (DVW)

\begin{tabular}{|c|c|c|c|c|c|c|}
\hline & & $\begin{array}{l}\text { WZC } \\
=5 \mid 2)\end{array}$ & & $\begin{array}{l}\text { DVW } \\
N=41 \text { ) }\end{array}$ & $\begin{array}{c}\mathrm{T}-/ X^{2}- \\
\text { waarde }\end{array}$ & p-waarde \\
\hline Leeftijd (M, SD) & 39,55 & $(13,57)$ & 35,53 & $(1 \mathrm{I}, 0 \mathrm{I})$ & $T=-I, 78$ & $*$ \\
\hline $\begin{array}{l}\text { Geslacht }(\mathrm{N}, \%) \\
\cdot \quad \text { Vrouw } \\
-\quad \text { Man }\end{array}$ & $\begin{array}{l}452 \\
55\end{array}$ & $\begin{array}{l}(89,15 \%) \\
(10,84 \%)\end{array}$ & $\begin{array}{l}38 \\
2\end{array}$ & $\begin{array}{l}(95,00 \%) \\
(5,00 \%)\end{array}$ & $x^{2}=1,44$ & \\
\hline $\begin{array}{l}\text { Opleidingsniveau (N, \%) } \\
\text { - Laaggeschoold } \\
\text { - Middengeschoold } \\
\text { Hooggeschoold }\end{array}$ & $\begin{array}{l}76 \\
400 \\
35\end{array}$ & $\begin{array}{l}(14,87 \%) \\
(78,28 \%) \\
(6,85 \%)\end{array}$ & $\begin{array}{l}4 \\
31 \\
2\end{array}$ & $\begin{array}{l}(10,81 \%) \\
(83,78 \%) \\
(5,41 \%)\end{array}$ & $X^{2}=10,87$ & \\
\hline $\begin{array}{l}\text { Functietype } \\
\text { - Zorgkundigen } \\
\text { - Verpleegkundigen } \\
\text { Overig personeel }\end{array}$ & $\begin{array}{l}303 \\
76 \mid \\
123\end{array}$ & $\begin{array}{l}(60,36 \%) \\
(5,14 \%) \\
(24,50 \%)\end{array}$ & $\begin{array}{l}21 \\
9 \\
11\end{array}$ & $\begin{array}{l}(51,22 \%) \\
(21,95 \%) \\
(26,83 \%)\end{array}$ & $x^{2}=1,74$ & \\
\hline Anciënniteit (M, SD) & 12,12 & $(10,10)$ & 3,53 & $(I, 50)$ & $T=-16,89$ & $* * *$ \\
\hline $\begin{array}{l}\text { Contractuele tewerkstelling (N, \%) } \\
\text { - Voltijds (meer dan } 34 \text { uur) } \\
\text { - Deeltijds (minder dan } 34 \text { uur) }\end{array}$ & $\begin{array}{l}155 \\
349\end{array}$ & $\begin{array}{l}(30,75 \%) \\
(69,25 \%)\end{array}$ & $\begin{array}{l}9 \\
32\end{array}$ & $\begin{array}{l}(21,95 \%) \\
(78,05 \%)\end{array}$ & $X^{2}=1,40$ & \\
\hline
\end{tabular}

Noot.'M' en 'SD' staan respectievelijk voor 'gemiddelde' en 'standaarddeviatie'.

$*_{\mathrm{p}}<, 05 ; *^{*} \mathrm{p}<, 0 \mathrm{I} ; * * * \mathrm{p}<, 00 \mathrm{I}$

\section{Resultaten}

De verschillen uit Tabel 4 geven een indicatie voor het verschil in werkeisen, regelmogelijkheden en werknemersuitkomsten tussen De Vierde Wand en conventionele woonzorgcentra. Hier wordt benadrukt dat de verschillen voornamelijk, maar niet uitsluitend te wijten zijn aan het al dan niet toepassen van continu verbeteren (CVB). Om zowel verklaring te geven voor de verschillen als ruimte te laten voor context, volgt na het kwantitatieve luik duiding op basis van interviewdata.

Analyse van de survey

Uit Tabel 4 blijkt dat De Vierde Wand significant hoger scoort dan conventionele woonzorgcentra op de dimensies voorspelbaarheid, autonomie, organiserende taken, bevlogenheid en innovatief werkgedrag, en lager op de dimensies taakvariatie, tijdsdruk, werkdruk en contactmogelijkheden. Al deze verschillen zijn in lijn met de hypothesen, behalve contactmogelijkheden. In tegenstelling tot de verwachting scoort De Vierde Wand voor dit kenmerk lager dan de referentiegroep. De verschillende scores op de dimensies kortcyclisch werk, volledigheid, emotionele belasting, informatievoorziening en herstelbehoefte zijn niet significant verschillend. De opmerkelijkste delta's of de opvallende discrepanties tussen de gemiddelden voor conventionele woonzorgcentra en CVB tonen dat de scores voor tijdsdruk $(-0,62)$, autonomie $(+0,37)$, organiserende taken $(+0,47)$ beduidend gunstiger zijn voor De Vierde Wand. Ook de gemiddelde score voor bevlogenheid $(+1,25)$ is opmerkelijk hoger in De Vierde Wand dan in de referentiegroep. 
Tabel 4 Vergelijking conventionele woonzorgcentra (CWZC) met De Vierde Wand (DVW)

\begin{tabular}{|c|c|c|c|c|c|c|c|}
\hline & & $M^{C W Z}$ & (SD) & $M^{D V V}$ & (SD) & $\Delta \mathbf{M}$ & $\begin{array}{c}\text { p- } \\
\text { waarde }\end{array}$ \\
\hline \multirow[t]{7}{*}{ Werkeisen } & Kortcyclisch werk & 2,37 & $(0,88)$ & 2,48 & $(1,04)$ & 0,11 & \\
\hline & Voorspelbaarheid & 2,91 & $(0,64)$ & 3,14 & $(0,57)$ & 0,23 & $* *$ \\
\hline & Taakvariatie & 2,93 & $(0,57)$ & 2,73 & $(0,58)$ & $-0,20$ & $*$ \\
\hline & Volledigheid & 3,25 & $(0,63)$ & 3,24 & $(0,77)$ & $-0,01$ & \\
\hline & Tijdsdruk & 3,32 & $(0,74)$ & 2,70 & $(0,57)$ & $-0,62$ & $* * *$ \\
\hline & Werkdruk & 2,64 & $(0,7 I)$ & 2,40 & $(0,7 I)$ & $-0,24$ & $*$ \\
\hline & Emotionele belasting & 3,72 & $(0,73)$ & 3,55 & $(0,74)$ & $-0,17$ & \\
\hline \multirow{4}{*}{$\begin{array}{l}\text { Regelmogelijk- } \\
\text { heden }\end{array}$} & Autonomie & 2,91 & $(0,77)$ & 3,28 & $(0,63)$ & 0,37 & $* *$ \\
\hline & Informatievoorziening & 3,44 & $(0,55)$ & 3,41 & $(0,4 I)$ & $-0,03$ & \\
\hline & Contactmogelijkheden & 3,11 & $(0,5 I)$ & 2,80 & $(0,4 I)$ & $-0,31$ & $* * *$ \\
\hline & Organiserende taken & 3,29 & $(0,74)$ & 3,76 & $(0,52)$ & 0,47 & $* * *$ \\
\hline \multirow{3}{*}{$\begin{array}{l}\text { Uitkomsten } \\
\text { zorgverleners }\end{array}$} & Herstelbehoefte & 2,88 & $(0,94)$ & 2,65 & $(1,17)$ & $-0,23$ & \\
\hline & Bevlogenheid & 4,06 & $(0,76)$ & 5,31 & $(1,08)$ & 1,25 & $* * *$ \\
\hline & Innovatief werkgedrag & 2,37 & $(0,88)$ & 2,48 & $(1,04)$ & $-0,11$ & $*$ \\
\hline
\end{tabular}

Noot. 'M' en 'SD' staan respectievelijk voor 'gemiddelde' en 'standaarddeviatie'.

$*_{\mathrm{p}}<, 05 ; *_{\mathrm{p}}<, 0 \mathrm{I} ; *^{*} * *_{\mathrm{p}}<, 00 \mathrm{I}$

Verklaringen op basis van interviews

In deze sectie worden de resultaten uit Tabel 4 geduid met data uit de interviews. De verklarende quotes van werkeisen en regelmogelijkheden worden achtereenvolgens besproken. Deze analyse wordt gevoerd met oog voor de organisatiespecifieke context van De Vierde Wand.

Ten eerste konden noch uit Tabel 4 noch uit de interviewdata verschillen opgemaakt worden omtrent kortcyclische taken. De zorgtaken zijn in beide woonvormen kortcyclisch van aard: CVB heeft hier geen invloed. De score op voorspelbaarheid ligt hoger in De Vierde Wand. $\mathrm{Nu}$ de was van bewoners volgens een nieuwe werkprocedure verloopt, moeten zorgverleners niet meer te pas en te onpas op en af van hun afdeling naar de centrale wasplaats in de kelderruimte lopen. Dit laat een betere planning toe en bijgevolg meer voorspelbaarheid in de job. De beduidend lage score voor tijdsdruk en werkdruk is zowel te wijten aan de bezettingsgraad als aan het continu streven naar efficiënter werken. Zorgverleners getuigen dat ze zowel door de hoge bezettingsgraad (= context) als door CVB een verlaagde werkdruk ervaren. Hoewel voor het merendeel van de geïnterviewden de werkdruk lijkt af te nemen ervaart een enkeling de veelheid aan regels als een verhoging van de werkdruk.

Soms vind ik het ook te veel wat er dan allemaal op komt te staan. Voor mij is dit soms een chaos van veranderende dingen. [...] Je moet heel veel onthouden over heel veel mensen. (Verpleegkundige, Interview 2) 
Op deze verpleegkundige na rapporteerden alle zorgverleners een verlaagde werkdruk na de CVB-interventie. Het valt op dat zorgverleners die CVB sterk naleven in vergelijking met vroeger nu door een verlaging van de werkdruk het gevoel hebben meer ruimte en tijd te vinden voor extra taken. Deze toenemende taakvariatie heeft ten eerste betrekking op bewonersgerichte taken: meer ruimte voor bewoners lijkt de bevlogenheid bij zorgverleners te verhogen, maar heeft geen verhogende invloed op de emotionele belasting. Een mogelijke verklaring hiervoor is dat in De Vierde Wand al sterk werd ingezet op bewonersgerichte zorg vóór de CVB-implementatie (= context).

Ik heb het gevoel dat ik nu tijd heb voor extra taken. Net had ik bijvoorbeeld tien minuten de tijd om met een bewoner te praten. Voor die man is dat een belangrijk moment, en als de werkdruk te hoog ligt, dan heb ik daar geen tijd voor. (Zorgkundige, Interview 4)

De toenemende taakvariatie heeft ten tweede betrekking op ondersteunende taken. Enkele zorgverleners zagen het belang hiervan voor de bewoners en de organisatie als geheel. Anderen rapporteerden echter dat ze meer wensen in te zetten op bewonersgerichte zorg dan op de ondersteunende onderhoudstaken die vroeger geen deel uitmaakten van hun takenpakket.

De tafeltjes vegen of het leegmaken van de vuilbakjes is voor ons [zorgkundigen] in principe net hetzelfde als dat die van de poets het incontinentiemateriaal zouden moeten weggooien. Eigenlijk is dat hun taak. Wat doen zij anders? Nu, dat is eigenlijk geen probleem [...] Soms denk je wel dat zij dat dan doen: zo hebben wij meer tijd voor wat anders ... (Zorgkundige, Interview 5)

Een dergelijke verbreding van het takenpakket blijkt op uiteenlopende manieren te worden ervaren. Sommige zorgverleners waarderen dat er meer ruimte is gekomen voor bewonersgerichte zorg, terwijl anderen het extra werk benadrukken. Op basis van Tabel 4 wordt in De Vierde Wand echter minder taakvariatie gepercipieerd dan in conventionele woonzorgcentra. Aangezien niet iedereen in dezelfde mate deelneemt aan het CVB - sommige medewerkers dagen niet of nauwelijks op aan de verbeterborden - wordt deze toegenomen taakvariatie niet door iedereen ervaren. In lijn hiermee ligt ook het resultaat voor jobvolledigheid. Hoewel medewerkers de mogelijkheden hebben betrokken te zijn bij de volledige werking, toont Tabel 4 aan dat ze de integratie van voorbereidende, uitvoerende en ondersteunende taken niet sterker ervaren dan in conventionele woonzorgcentra.

Wat betreft de regelmogelijkheden waren de geïnterviewden ten eerste overwegend positief over de ruimte om zelf vorm te geven aan de eigen werkmethoden en de problemen zelfstandig aan te pakken. Hieruit blijkt een toegenomen mate van autonomie. De zorgverleners herhaalden vaak dat het management hun het vertrouwen geeft: zij bieden de mogelijkheden en scheppen het kader waarbinnen de zorgverleners kunnen manoeuvreren. Doordat zorgverleners het werk zelf kunnen organiseren leidt CVB in de ogen van de meeste zorgverleners tot een vermindering van stress en een hogere bevlogenheid, in lijn met de theorie. 
Het is fijn dat we problemen van de bazen nu zelf mogen oplossen. Zij geven ons de werking van hun rusthuis in handen [...] Door [CVB] weet je dat de problemen opgelost worden en je niet met iets hoeft te blijven zitten. [CVB] heeft mijn motivatie wel wat verhoogd omdat je hier vroeger mee bleef zitten. (Zorgkundige, Interview 4)

Tabel 4 geeft aan dat er geen verschil is wat betreft informatievoorziening. Dit is contra-intuïtief, aangezien de dagelijkse bijeenkomsten aan het verbeterbord net zouden moeten leiden tot een verbeterde onderlinge uitwisseling van informatie, en meer structuur en duidelijkheid over het te verrichten werk. De volgende zorgkundige en voorstander van het continu verbeteren getuigt ook van een verbeterde informatievoorziening ten opzichte van de periode voor het toepassen van CVB.

Ik vind dat er een beter overzicht is van de problemen. Deze zijn daardoor gemakkelijker op te lossen. (Zorgkundige, Interview 11)

Niet alle zorgverleners denken er op deze manier over. Zo is een deel van de zorgverleners pertinent afwezig tijdens de verbetermomenten en worden de standaardprocedures niet altijd nageleefd. Bijna alle geïnterviewden geven aan dat het zogenaamde verwateren van verbetervoorstellen en de afwezigheid van zorgverleners aan de verbeterborden bron van frustratie zijn voor de voorstanders van CVB. Beide bronnen van frustratie verklaren de lage score voor contactmogelijkheden uit Tabel 4. Daarnaast tonen bovenstaande quotes waarom de informatievoorziening in De Vierde Wand niet hoger ligt dan voorspeld: heel wat medewerkers zijn door afwezigheid gewoonweg niet op de hoogte van de nieuwe standaardprocedures. Afwezigheid aan de verbeterborden en slordigheid in het handhaven van de nieuwe standaarden zorgen bijgevolg voor lichte gelatenheid bij de voorstanders van CVB.

Het enige probleem vind ik dat collega's soms niet meewerken met de afspraken die er gemaakt zijn [...] Uw moed geraakt een beetje op als andere collega's niet meedoen want dan wordt uw inzet niet beloond [...] Ik heb meer zin om mij in te zetten, maar de ene dag wel meer dan de andere, puur omdat sommige collega's niet meewerken. Soms denk ik dan: 'Heb ik hier zoveel werk voor gedaan?' (Zorgkundige, Interview 1) De dingen die we bespreken gaan dan vaak een tijdje goed, maar vervolgens verwateren die dingen weer. Dan moet je je collega's dus opnieuw aanspreken, dat is dus een teken dat ze het niet doen zoals het moet of dat het een sleur wordt. (Zorgkundige, Interview 4)

Verder blijft het geven van feedback voor enkelen een gevoelig punt: het signaleren van problemen wordt soms nog opgevat als persoonlijke kritiek. Vooral het aanspreken op het niet naleven van afgesproken regels verloopt voor enkelen moeizaam. Dus ook het moeizaam aanspreken verduidelijkt de lage score voor contactmogelijkheden uit Tabel 4. Dit gegeven kan opnieuw leiden tot verwatering en verdere frustratie bij de voorstanders van CVB.

Ik denk dat sommige collega's nu wat minder goed met mekaar kunnen opschieten, omdat de dingen nu benoemd worden en sommigen zich hierdoor meer aangesproken 
voelen. Maar met anderen heb je dan net weer een hechtere band, net omdat je elkaar rechtstreeks kan aanspreken. (Zorgkundige, Interview 7)

De zorgverleners die de richtlijnen van CVB keurig nastreven merken op dat allerlei aspecten nu net beter bespreekbaar zijn dan vroeger. Constructieve feedback en veelvuldige contactmogelijkheden resulteren voor deze voorstanders dus in een verbeterde kwaliteit van de arbeid. In het volgende citaat maakt een zorgverlener duidelijk dat deze nieuwe manier van communiceren het geven van feedback effectief faciliteert. Ze getuigt net van een verbeterde samenwerking. Ze merkt dat problemen bespreekbaar gemaakt worden en dat ook haar collega's hier baat bij hebben.

Vroeger loste je dat [probleem] in je eentje op, maar in je eentje krijg jij zoiets niet opgelost, [...] je hebt iemand nodig die dat samen met jou oplost, je hebt medewerking nodig om probleem op te lossen. (Zorgkundige, Interview 6)

In lijn hiermee brachten de voorstanders aan dat er meer eerlijkheid is ontstaan tussen de zorgverleners onderling. In de periode voor CVB werd er volgens hen sneller naar het diensthoofd gelopen. Dankzij meer openheid spreken zorgverleners elkaar nu meteen rechtstreeks aan. Wanneer zich problemen voordoen wordt volgens hen steeds abstractie gemaakt van de personen die hiermee in aanraking kwamen. Er wordt door CVB dus niet met de vinger gewezen naar die ene collega die de mist in ging. Wel wordt samen naar een oplossing gezocht voor het probleem dat zich voordoet. Tabel 4 geeft echter weer dat CVB overwegend leidt tot negatieve contactervaringen in vergelijking met conventionele woonzorgcentra. Het samenvattende besluit is hier dat CVB in De Vierde Wand het potentieel in zich heeft om intensiever te communiceren over het werk. Dit kan positief en negatief uitdraaien voor zorgverleners. In De Vierde Wand zijn verwatering, het geven van feedback en de afwezigheid aan het verbeterbord elementen die de regelmogelijkheden van de voorstanders van CVB belemmeren. Net als bij conventionele woonzorgcentra, heeft men in De Vierde Wand nood aan herstel aan het einde van de werkdag: hetzij omdat men gefrustreerd is door het verwateren en het onvoldoende toepassen van CVB, hetzij omdat men zich niet bezighoudt met CVB. Anderzijds toont de volgende laatste quote aan dat de bevlogenheid in dit woonzorgcentrum ten opzichte van de vorige werkplek is toegenomen. Voor een deel vindt de zorgkundige verklaring bij de geborgen teamsfeer in De Vierde Wand. Toch linkt deze zorgverlener CVB duidelijk aan samenwerken, aan zoeken naar oplossingen en aan de bevlogenheid van zorgverleners.

Op mijn vorig werk was mijn motivatie sowieso minder, want daar zat ik in een team waar je niet zo opgevangen werd, waar je minder kon communiceren, of waar je dingen minder bespreekbaar kon maken [...] Dan zat je telkens met dezelfde problemen en dezelfde frustraties, omdat er niets aan gedaan wordt. Hier kan je de dingen door lean bespreekbaar maken en zeggen wat er op je maag ligt en wat eraan gedaan kan worden. Zo proberen we samen tot een oplossing te komen. [...] Je leert bij van collega's. Je wordt er echt bij geholpen. Hier word je au sérieux genomen. Mensen bloeien daardoor meer open. (Zorgkundige, Interview 3) 


\section{Conclusie}

Uit eerdere studies komt naar voren dat de invloed van continu verbeteren (CVB) op de kwaliteit van de arbeid niet leidt tot eenduidige resultaten (Benders, 2017; d'Andreamatteo et al., 2015; Neirotti, 2019). Dit is voornamelijk te wijten aan een verschil in motivatie en methodiek om CVB te implementeren (Benders, 2017; Hasle, 2014; Ortmann, 1995). In dit artikel gingen we na wat de invloed van CVB is op de kwaliteit van de arbeid in een woonzorgcentrum dat CVB sterk volgens het boekje toepast. Hiervoor baseerden we ons op het job demands-control model van Karasek (1979). De belangrijkste conclusie is dat een strikte naleving van CVB in een woonzorgcentrum resulteert in een verlaging van werkeisen en een verhoging van regelmogelijkheden.

Enerzijds ervaren zorgverleners in De Vierde Wand minder tijdsdruk en minder werkdruk. De vrijgekomen tijd wordt ingevuld met andere taken. Uit de interviews blijkt dat de bevlogenheid van zorgverleners toeneemt wanneer dit bewonersgerichte taken zijn, maar dat deze bevlogenheid afneemt wanneer het gaat over indirecte taken.

Anderzijds ervaren zorgverleners een verhoging van de regelmogelijkheden zoals autonomie en de mogelijkheid tot het organiseren van taken. De quotes tonen aan dat er al een open context was in De Vierde Wand, maar dat inbreng en medezeggenschap dankzij CVB nog substantieel zijn toegenomen. Dit heeft onder meer geleid tot verhoogde bevlogenheid. Daarentegen is het opvallend dat de mogelijkheid tot het uitwisselen van informatie in De Vierde Wand niet verschilt van conventionele woonzorgcentra. Verder werd ook een onverwacht lage score voor contactmogelijkheden gevonden. Dit gaat in tegen de theoretische assumptie en stelt in vraag wat informatievoorziening en vlot overleg nu precies hindert. Ten eerste is het zo dat niet alle zorgverleners komen opdagen tijdens de verbetermomenten. Ten tweede hebben zorgverleners moeite met het constructief aanbrengen van verbeterpunten. Ten slotte reageren de betrokken zorgverleners gefrustreerd wanneer de afgesproken standaardprocedures niet (keurig) nageleefd worden. Deze reactie kant zich niet tegen CVB, maar is gericht op het slordig omspringen met CVB. Met andere woorden: de onvrede van de voorstanders wordt niet veroorzaakt door $C V B$, maar juist doordat niet alle collega's CVB ernstig genoeg nemen. Op termijn zit hier een risico voor CVB: haken de gemotiveerde voorstanders van CVB af uit frustratie voor het gedrag van collega's of niet? Het moet gezegd zijn dat hier ook wel heel wat lovende klanken zijn over de communicatie. Zeker de voorstanders van CVB merken dat ze iedereen kunnen aanspreken over wat dan ook. Volgens hen is het sociale klimaat op de werkvloer als geheel verbeterd.

De conclusie is dat CVB in De Vierde Wand een positieve invloed heeft op de kwaliteit van de arbeid, maar ook dat er hier aan CVB zelf nog een en ander valt te verbeteren. Aangezien CVB nog niet door alle zorgverleners gewaardeerd wordt, werd geen verschil gevonden met betrekking tot de herstelbehoefte. Het komt echter wel sterk naar voren dat de zorgverleners in De Vierde Wand een hogere motivatie en bevlogenheid hebben bij de organisatie. We concluderen dat CVB in De Vierde Wand over het algemeen resulteert in lagere werkeisen, hogere regelmogelijkheden en verhoogde bevlogenheid bij zorgverleners. 
Hiermee is niet gezegd dat het toepassen van CVB elders tot dezelfde resultaten zal leiden. Immers, CVB kan op verschillende manieren worden ingezet, met verschillende doelen, in uiteenlopende contexten. In De Vierde Wand speelt het management een actieve rol in de ondersteuning van CVB. Een enthousiasmerend management lijkt een noodzakelijke voorwaarde te zijn voor een succesvolle implementatie van CVB met een positieve kwaliteit van de arbeid tot gevolg. Uit vervolgonderzoek zou moeten blijken hoe duurzaam dit effect is. Wanneer men dezelfde methoden drie jaar na de eerste meting opnieuw toepast, kan duidelijk worden (1) in welke richting de kwaliteit van de arbeid evolueert, en (2) of de pijnpunten van vandaag uit de organisatie geweerd werden. Nog ander onderzoek zou de invloed van CVB kunnen vergelijken met deze van andere innovatieve interventies op de kwaliteit van de arbeid in de woonzorgsector. Op deze manier zouden we tot best practices kunnen komen om gepast antwoord te bieden op de prangende vraagstukken uit de ouderenzorg.

\section{Beleidsimplicaties}

Over de gevolgen van CVB voor werknemers bestaat heel wat scepsis. Wantrouwen is inderdaad gezond, maar mag niet ontaarden in het verwerpen van alle door CVB geïnspireerde interventies. In een relatief hectische werkomgeving als een woonzorgcentrum kan het onderdeel CVB positief uitpakken voor de kwaliteit van de arbeid, zoals deze casestudie laat zien. Het inzetten van CVB kan in Vlaanderen helpen om cruciale dimensies van de werkbaarheidsagenda aan te pakken. Hierbij wordt voornamelijk ingezet op het verminderen van tijdsdruk, werkdruk en emotionele belasting, om zo de werkbaarheidsindicatoren in de zorg in een positief daglicht te stellen. De Vlaamse minister van Welzijn, Gezondheidszorg en Gezin ijvert zo voor een stressreductie, een toegenomen bevlogenheid ten aanzien van de job, meer leermogelijkheden en een verbeterde werk-privéverhouding voor het zorglandschap in Vlaanderen (Van Deurzen, 2017, pp. 50-52). De ervaring bij De Vierde Wand laat zien dat CVB kan helpen om de eerste drie aspecten te verbeteren. In Nederland speelt een vergelijkbare problematiek: de 'combinatie van hoge taakeisen en lage autonomie [...] komt het meeste voor in de horeca, onderwijs en gezondheidszorg', aldus de meest recente uitgave van de Arbobalans (TNO, 2019, pp. 41-43). Met dit in het achterhoofd, lijkt het zowel voor België als voor Nederland nuttig dat beleidsmakers in de zorg meer inzetten op CVB en de invloed op de kwaliteit van de arbeid.

\section{Literatuur}

Agentschap Zorg en Gezondheid. (2017). Interpretatie van de erkenningsvoorwaarden en -normen voor woonzorgcentra (WZC), rust-en verzorgingstehuizen (RVT) en centra voor kortverblijf (CVK) ingebed in een woonzorgcentrum. Brussel: Departement Welzijn, Volksgezondheid en Gezin, afdeling Zorginspectie.

Andersen, H., Røvik, K.A., \& Ingebrigtsen, T. (2014). Lean thinking in hospitals: Is there a cure for the absence of evidence? A systematic review of reviews. BMJ open, 4(1), e003873.

Ballé, M., \& Régnier, A. (2007). Lean as a learning system in a hospital ward. Leadership in health services, 20(1), 33-41.

Baxter, P., \& Jack, S. (2008). Qualitative case study methodology: Study design and implementation for novice researchers. The Qualitative Report, 13(4), 544-559. 
Benders, J. (2017). Lekker lean werken? Tijdschrift voor Arbeidsvraagstukken, 33(2), 214216.

Benders, J., Bleijerveld, H., \& Schouteten, R. (2017). Continuous improvement, burnout and job engagement: A study in a Dutch nursing department. International Journal of Health Planning and Management, 32(4), 481-491.

Benders, J., \& Missiaen, C. (2013). Zorgvernieuwers: Betere zorg door anders organiseren. Tielt: Lannoo Campus.

Benders, J., Van Grinsven, M., \& Ingvaldsen, J. (2019). The persistence of management ideas: How framing keeps lean moving. In A. Sturdy, S. Heusinkveld, T. Reay, \& D. Strang (Eds.), The Oxford Handbook of Management Ideas (pp. 271-285). Oxford: Oxford University Press.

Bourdeaud'hui, R., Janssens, F., \& Vanderhaeghe, S. (2017). Vlaamse werkbaarheidsmonitor 2016 - werknemers: Rapport. Brussel: Stichting Innovatie \& Arbeid SERV.

Conti, R., Angelis, J., Cooper, C., Faragher, B., \& Gill, C. (2006). The effects of lean production on worker job stress. International Journal of Operations \& Production Management, 26(9), 1013-1038.

Corley, K.G., \& Gioia, D.A. (2011). Building theory about theory building: What constitutes a theoretical contribution? Academy of Management Review, 36(1), 12-32.

d'Andreamatteo A., Ianni, L., Lega, F., \& Sargiacomo, M. (2015). Lean in healthcare: A comprehensive review. Health Policy, 119, 1197-1209.

De Rooij, A.H., Luijkx, K.G., Schaafsma, J., Declercq, A.G., Emmerink, P.M., \& Schols, J.M. (2012). Quality of life of residents with dementia in traditional versus smallscale long-term care settings: A quasi-experimental study. International Journal of Nursing Studies, 49(8), 931-940.

De Treville, S., \& Antonakis, J. (2006). Could lean production job design be intrinsically motivating? Contextual, configurational, and levels-of-analysis issues. Journal of Operations Management, 24(2), 99-123.

Demerouti, E., Bakker, A.B., Nachreiner, F., \& Schaufeli, W.B. (2001). The job demandsresources model of burnout. Journal of Applied Psychology, 86(3), 499.

Drotz, E., \& Poksinska, B. (2014). Lean in healthcare from employees' perspectives. Journal of Health Organization and Management, 28(2), 177-195.

Goetghebeur, E., \& Sevenants, A. (2017). Experten-panel kwaliteit van leven: De resultaten. Kwaliteit van leven in woonzorgcentra. Brussel: Vlaams Indicatorenproject Woonzorgcentra.

Håkansson, M., Holden, R.J., Eriksson, A., \& Dellve, L. (2017). Managerial practices that support lean and socially sustainable working conditions 1 . Nordic Journal of Working Life Studies, 7(3), 63-84.

Hasle, P. (2014). Lean production - An evaluation of the possibilities for an employee supportive lean practice. Human Factors and Ergonomics in Manufacturing \& Service Industries, 24(1), 40-53.

Huo, M.L., \& Boxall, P. (2018). Are all aspects of lean production bad for workers? An analysis of how problem-solving demands affect employee well-being. Human Resource Management Journal, 28(4), 569-584.

Karasek, R.A. (1979). Job demands, job decision latitude, and mental strain: Implications for job redesign. Administrative Science Quarterly, 24(2), 285-308.

Karasek, R.A., \& Theorell, T. (1990). Healthy work. New York: Basic Book.

Karimi, L., Leggat, S.G., Donohue, L., Farrell, G., \& Couper, G.E. (2014). Emotional rescue: The role of emotional intelligence and emotional labour on well-being and job-stress among community nurses. Journal of Advanced Nursing, 70(1), 176-186.

Liker, J.K. (2004). The Toyota Way. New York: McGraw-Hill.

Neirotti, P. (2019). Work intensification and employee involvement in lean production: New light on a classic dilemma. International Journal of Human Resource Management. Te verschijnen.

Ortmann, G. (1995). Formen der Produktion: Organisation und Rekursivität. Wiesbaden: Westdeutscher Verlag.

Proost, K., De Witte, H., De Witte, K., \& Evers, G. (2004). Burnout among nurses: Extending the Job Demand-Control-Support model with work-home interference. Psychologica Belgica, 44(4), 269-288. 
Rouppe van der Voort, M., \& Benders, J.G.J.M. (red.). (2012). Lean in de zorg: De praktijk van continu verbeteren. Den Haag: Boom Lemma uitgevers.

Schaufeli, W.B., \& Bakker, A.B. (2004). Bevlogenheid: Een begrip gemeten. Gedrag en Organisatie, 17, 89-112.

TNO. (2019). Arbobalans 2018: Kwaliteit van de arbeid, effecten en maatregelen in Nederland. Leiden: TNO.

Tummers, L.G., Groeneveld, S.M., \& Lankhaar, M. (2013). Why do nurses intend to leave their organization? A large-scale analysis in long-term care. Journal of Advanced Nursing, 69(12), 2826-2838.

Ulhassan, W., Von Thiele Schwarz, U., Westerlund, H., Sandahl, C., \& Thor, J. (2015). How visual management for continuous improvement might guide and affect hospital staff: A case study. Quality Management in Healthcare, 24(4), 222-228.

Van Deurzen, J. (2017). Residentiële ouderenzorg, een échte thuis voor kwetsbare personen: Een stevige uitdaging voor de samenleving én zorgaanbieders. Conceptnota. Brussel: Agentschap Zorg en Gezondheid.

Van Hootegem, G., Huys, R., Dhondt, S., \& Kraan, K. (2014). Werknemersvragenlijst betrokkenheid, welzijn en innovatie op het werk. In G. Van Hootegem, R. Huys, \& G. Maes (red.), Meten en veranderen: Instrumenten bij het nieuwe organiseren (pp. 6175 \& 169-183). Leuven/Den Haag: Acco.

Vermeerbergen, L. (2018). Mountains of care: Organisational redesign and quality of working life in nursing homes (Doctoral Dissertation). Leuven: KU Leuven.

Vermeerbergen, L., Van Hootegem, G., \& Benders, J. (2016). Kwaliteit van arbeid in kleinschalige en genormaliseerde woonzorgcentra. Tijdschrift voor Arbeidsvraagstukken, 32(4), 377-391.

Von Thiele-Schwarz, U., Nielsen, K.M., Stenfors-Hayes, T., \& Hasson, H. (2017). Using kaizen to improve employee well-being: Results from two organizational intervention studies. Human Relations, 70(8), 966-993.

Walshe, K. (2007). Understanding what works - and why - in quality improvement: The need for theory-driven evaluation. International Journal for Quality in Health Care, 19(2), 57-59.

Yin, R.K. (2015). Qualitative research from start to finish. New York/Londen: The Guilford Press. 